\title{
The Unruly, the Mut(ilat)ed, the Ailing: Corporeality as a Space of Subversion in J. M. Coetzee's Fiction
}

\author{
Kamel Abdaoui \\ Department of English, Faculty of Arts and Humanities \\ University of Sousse,Tunisia
}

\begin{abstract}
This paper addresses corporeality as a space of subversion to hegemonic discourses in J. M. Coetzee's fiction. The body is not only elusive to representation but it is also entrusted with a certain degree of authority that allows it to contravene the systems of normalization imposed by dominant discourse. The paper tends to appropriate poststructuralism and postcolonialism as its main theoretical grid to argue that corporeality in Coetzee's novels is deployed as a fluid construct that offers a space of interaction between subjectivities beyond the rigid contours of discursive representation. In Dusklands, the clear-cut demarcations erect between the Self and the Other often blur and disintegrate while facing the permeability and extensiveness of the body. In Waiting for the Barbarians and Foe, however, the mutilated and silenced body of the Other is presented as a space of resistance to the Empire's attempts to inscribe its statement of powerviolently. It is only the diseased body of Mrs. Curren, in Age of Iron, which transforms into an intersubjective space of reciprocity between Self and Other that is capable of overcoming the fixed barriers between subjects. Being an active site of contestation between subjectivities, the textual construction of corporeality in Coetzee's aforementioned novels offers creative opportunities of becoming and grants an imaginative understanding of otherness outside the limits of the logic of binarism encapsulated in colonial and imperialist discourses.
\end{abstract}

Keywords: colonialrepresentation, corporeality, identity, resistance, subversion

Cite as: Abdaoui , K. (2017). The Unruly, the Mut(ilat)ed, the Ailing: Corporeality as a Space of Subversion in J. M. Coetzee's Fiction. Arab World English Journal for Translation \& Literary Studies, 1(2). DOI:http://dx.doi.org/10.24093/awejtls/vol1no2.2 
AWEJ for Translation \& Literary Studies volume, 1 Number 2, May2017

The Unruly, the Mut(ilat)ed, the Ailing: Corporeality as a Space

Abdaoui

\section{Introduction}

Corporeality occupies a subversive position in the fiction of Coetzee. Rather than presenting the body as an appending marker of identity, Coetzee (1986) depicts the "bodies are their own signs" (p. 157). By representing the disturbing physical presence of some of his characters, Coetzee manages to enact the body's elusive but vital response to dominant discourse. In Giving Offense: Essays on Censorship, Coetzee emphasizes the limitation of rational thinking in assimilating all forms or experiences of existence. For Coetzee, since "reason is a form of power with no in-built sense of what the experience of powerlessness might be," it falls short of explaining what "cannot itself be the object of some other method of explanation more all-inclusive than itself" (p. 4). The body seems to possess a potential for resistance despite its powerlessness. By substantiating the role of corporeality as a space of mutuality between subjectivities in his texts, Coetzee seeks to dismantle the binary oppositions defining the Self/Other relationship.

This paper attempts to demonstrate that Coetzee's fictional texts further the invalidation of the logic of binarismthrough the deployment of corporeality as a subversive trope. My theoretical approach to the issues of corporeality, particularly its functioning as a deconstructive tool,first draws on the Foucauldian conceptualization of thepower structures of dominant discourse. Protagonists such as Dawn, Jacobus, the Magistrate, Susan Barton, and Mrs. Curren fail to articulate their own statementsoutsidethe contours of the totalizing discourse of the Self. Further, this paper appropriates the postcolonial theories of Bhabha, Ashcroft, and Spivak that define counter-discourse as a form of resistance that can challenge the power hierarchy imposed by hegemonic discourse(s). In the encounter between discourses of the margin and the "standard code" (Ashcroft, 2001a, p. 65), the colonized body is viewed not only as a locus of colonial "fetishization" (Bhabha, 1994, p. 132) but also as a space of negotiation of identity.

\section{1. (Dis)Embodied Subjectivity}

In his attempt at revisioning the Enlightenment pronouncements on human subjectivity, Coetzee (1974) overtly calls into question the allegedly solipsistic and disembodied Cartesian subjecthood in his first novel, Dusklands, "[T] he voice which our broadcasting projects into Vietnamese homes is the voice of neither father nor brother. It is the voice of the doubting self, the voice of René Descartes driving his wedge between the self in the world and the self that contemplates that self' (p. 20). Against a Cartesian consciousness that postulates an ontological dichotomy between the body, as a mechanical corporal substance, and the mind, as an immaterial essence and the seat of reason and consciousness, Coetzee proposes corporeality as a crucial component of subjectivity. He particularly emphasizes the centrality of the body as space of colonial mapping and imprinting, a space where the constructed demarcations between Self and Other are violently set. When Coetzee (1992) is invited to comment on the role of the body in his fiction, he states:

If I look back over my own fiction, I see a simple (simple-minded?) standard erected. That standard is the body. Whatever else, the body is not that which is not, and the proof that it is is the pain it feels. The body with its pain becomes a counter to the endless trials of doubt [...]. [I]t is not that one grants authority to the suffering body: the suffering body takes [emphasis added] this authority: that is its power. (p. 248). 
Coetzee explicitly puts under scrutiny Cartesian doubt and the essentiality attributed to the body as a disempowered ancillary to the human subjectivity. The infliction of pain is related to the exertion of power on the body, an offense that renders it undoubtedly visible and present. Coetzee identifies the body not only as the 'standard' of his own fiction, but also as a standard whose corporeality validates its 'authority' as an undeniable truth exceeding the strictures of rational representation.

In the first novella of Dusklands, "The Vietnam Project," the deranged personality of Eugene Dawn, the major protagonist, reveals the contention between a disembodied solopsistic subjectivity that tends to discipline the body functions and an out-of-proportion corporeality that resists appropriation and containment. Throughout the narrative, he incessantly refers to himself as a "thinker, a creative person, one not without value to the world" (p. 1). Epitomizing Cartesian dualistic conception of the human subject, Dawn deems his mind a unique locus of his subjectivity. He elevates it over the body which, conversely, is viewed as a physical limitation to his cognitive and contemplative faculties. On every occasion Dawn refers to his body and its functions, he overtly expresses his contempt for it by describing it in a very deprecating way.

Whenever Dawn wants to concentrate on his intellectual work and get "engaged in a liberating creative act," his fingers "curl and clench" in the palms of his hands and his toes also "curl into the soles of his feet" (p. 4). The incongruous relation between Dawn's mental faculties and his physical activities seems to be ineradicable. More than once, he expresses his repulsion from his body,"the pressure of my enemy body. I must have poise of mind to do my creative work" (p. 8). His body constitutes a sort of limitation as well as hindrance to his intellectual activities, "My spirit should soar into the endless interior distances, but dragging it back, alas, is this tyrant body" (p. 32). For the sake of maintaining his autonomy, Dawn sets the lines between an aberrant and refractory body, which is inclined to resist control and constriction, and a freefloating, 'liberating,' and transcendental mind that seeks to subjugate and suppress that body. The eccentric way in which Dawn refers to his body as 'enemy, 'tyrant,' and "parasite starfish" (p. 7), reveals a dichotomous conception of the body as an ontologically distinct substance situated outside the contours of consciousness, the exclusive seat of rationality.

The disparity between Dawn's symbolic self-representation and his corporeal presence reaches a climax when he kidnaps his own son, Martin, and in a reckless but spontaneous act of panic he hurts him with a knife. Dawn becomes so submerged by poignant anguish that he fails to control his physical reactions. As a result, his emotional frustration becomes very intense and bursts into the irrational assault upon his son:

When the police broke in I panicked [...]. Panic is a natural first reaction. That is what happened to me. I no longer knew what I was doing. How else can one explain injuring one's own child, one's own flesh and blood? I was not myself [emphasis added]. In the profoundest of senses, it was not the real I who stabbed Martin. (p. 44)

The act of exempting his mind from any responsibility by focusing exclusively on his physical reactionsallows Dawn to maintain the gap between his irrational attack against his own sonand his self-perception as a rational person. Instead of facing his feelings of guilt and shame of 
having aggressed his child, he concentrates solely on the uncontrollable impulses of his body,"my consciousness is shooting backwards, at a geometrically accelerating pace, according to a certain formula, out of the back of my head, and I am not sure I will be able to stay with it" (42).His inability to control his physical responses destabilizes his professed Cartesian ontological division between his corporeality and his rational thinking, and result in such an irrational behavior.

At the end of the narrative, Dawn ends up detained in a mental institution. In an act of self-analysis, he is depicted contemplating the events of his life:"I am eager to confront life a second time, but I am not impatient to get out. There is still my entire childhood to work on [...]. In my cell [...] I ponder and ponder. I have high hopes of finding whose fault I am" (p. 49). Dawn's highly esteemed self-consciousness ironically reverses into self-delusion. The dysfunction of Dawn's identity unveils the fact that the rationality and coherence of Cartesian solipsistic paradigm of subjectivity is by no means irreversible or infallible. It is his corporeality that challenges the authority of such a discourse by rendering it susceptible to doubt.

Self-delusion and detachment also characterize Jacobus, the main protagonist of the second novella, "The Narrative of Jacobus Coetzee." Bearing the misconception that the Hottentots are savage creatures, Jacobus comes to the "land of the Great Namaqua" (p. 66) assuming an air of superiority and ego-centrism, especially, when he imagines that their wellbeing depends on his own person. While meditating on his forthcoming encounter with Namaqua people, he muses, "Perhaps on my horse and with the sun over my right shoulder I looked like a god, a god of the kind they did not yet have. The Hottentots are a primitive people" (p. 71). After enduring many adversities and hazards during the trip with his Hottentot servants, Jacobus accredits all the merit to himself:

My Hottentots and my oxen had given me faithful service; but the success of the expedition had flowed from my own enterprise and exertions. It was I who [emphasis added] planned each day's march and scouted out the road. It was I who conserved the strength of the oxen so that they should give of their best when the going was hard. It was I who saw that every man had food. It was I who, when the men began to murmur on those last terrible days [...] restored order with a firm but fair hand. They saw me as their father.They would have died without me [emphasis added]. (p. 64)

Jacobus's assumed god-like posture as well as the reiteration of the phrase, "It was I who" did such and such a thing, denote the degree of narcissism and self-obsession he attains. Wholly engulfed in his self-conception, Jacobus imagines that everything in the external world issues from and depends on his solipsistic Self, hence his assumption that his slaves and oxen would have perished without his Deus Ex Machina-like intervention.

In his first contact with the indigenous people, Jacobus imagines that he can gain a foothold in his transaction with them by means of his possessions which they value. As soon as they reject his offer and dispossess him of his goods and share them all among themselves, he collapses by losing his temper and his sense of self-assurance. Like Dawn in the first narrative, Jacobus's autonomous disposition does not hold long. Soon after his first contact with Bushman people, he falls sick and his poor health exacerbates to the extent that he becomes totally 
dependent on the very people he has so far regarded as 'heathen,' 'primitive,' and 'savage.' His weak physical condition does not only unveil his vulnerability as a human being but also deflates his aggrandized self-image of being a god in the eyes of the Hottentots.

The fact of becoming totally dependent on the mercy of the Other reverses his position of superiority. Ironically, shortly after denigrating the Hottentots for what he regards as 'unclean' practices, he himself shifts to a worse position, that of the abominable Other: "I wished to return to my reveries but could not. I had fallen into an irritating spell of sobriety and anxiety. An eruption was forming on my left buttock an inch or so from my anus" (p. 82). Because of his illness, Jacobus is quarantined in a "hut for menstruating women" (p. 71) situated on the fringe of the village. Blinded by his colonialist posture, Jacobus not only excludes the possibility that this act can be understood as a precautionary measure against a probable contamination, but he also interprets it as an act of humiliation and degradation. Therefore, his position as a 'god' for those he considers as both savage and primitive Hottentots is both disconfirmed and subverted. Ironically, the act of being quartered in such an isolated and marginalized place reserved for menstruating women makes Jacobus feel that he is doubly offended as a male colonizer by the very Hottentots who have so far constituted the object of colonial othering and stereotyping.

The reverse othering to which Jacobus is subjected casts him into a state of doubt and perhaps near nullification. In the scene where he sneaks between the huts to watch a Hottentot dance, Jacobus recognizes his state of specter to which he is reduced: "I crossed the stream and moved among the huts, a ghost or a scraggy killjoy ancestor" (p. 85). As his existence is put into question, Jacobus engages into a number of incidents to regain his position as a colonizer. However, all his efforts to recuperate his lost stature as a superior and god-like figure are to no avail. This peaks in scene in which he turns into an object of ignominy and ridicule by Hottentot children while washing in the river:

I was subjected to indignities, dragged to my feet and thrown down, buffeted from hand to hand, showered with dust, and grit [...]. To adversaries ignorant or contemptuous of the principle of honour these aims were not incompatible. We could both be satisfied yet. Naked and filthy I knelt in the middle of the ring with my face in my hands, stifling my sobs in the memory of who I was. Two children raced past me [...]. Long stillness, whispers, laughter. Bodies fell upon me, I was suffocated and pinned to the ground [...]. I screamed with pain and shame. (pp. 90-91)

The above scene sums up the desperate and paranoid state of mind into which Jacobus is caught while being hospitalized by the native tribes. He seems to over-react to the Hottentot children's spontaneous and almost harmless kidding. He takes simple childish teasing for a matter of 'honour,' 'indignity,' and 'shame.' Entirely immersed into his dichotomous colonialist mindset, Jacobus becomes less sensitive to the cultural differences between European colonialists and the native tribes whom, despite their hospitability, he still regards them as his 'adversaries.' In an act of madness, he engages in a fight with their children and savagely mutilates a boy by ferociously tearing his ear off with his own teeth, "The ear I had bitten off was not forgotten. 'Go. Leave us. We cannot give you refuge any longer"” (p. 91). Jacobus's despicable behavior is countered by a pacific reaction on the part of the Hottentots who, though situated in a position of power, restrain 
themselves from retaliating with violence against his unjustifiable feral attack against their children. They have peacefully asked him to leave their lands. Instead of proving his status as a civilized white colonist, a tamer of the wild, a frontiersman, a mapmaker, and a missionary to the "heathens" (57), Jacobus ends in a state of degradation and doubt when he becomes more savage and barbarous than the Hottentots he has (mis)represented as such.

\section{The Mut(ilat)ed Body}

Waiting for the Barbarians presents the reader with an imaginary landscape, a border town where the Magistrate, the narrator of the story, makes it his personal concern to probe, to care for, and to heal the mutilated body of the barbarian girl, the epitome of otherness in the narrative. However, the Magistrate's peaceful and often compromising way of governing the town, which is mixed with some very personal drives, is disrupted with the emergence of the figure of Colonel Joll from the imperial center, the 'Third Bureau,' to the border outpost with the mission of suppressing and casting off the specter of a possible rebellion by the native people, called 'barbarians.'

As soon as he sets foot on the outpost, Col. Joll starts incarcerating and torturing the prisoners. He deliberately mutilates the eyes and feet of the barbarian girl not just to intimidate the native people for any potential threat to imperial domination of space. It is rather to imprint the Empire's statement of power symbolized by the "tiger rampant" (Coetzee, 1980, p. 146), on the Other's body. The ultimate aim of the acts of torture committed against the barbarian captives during interrogation is barely to attain true confession. It is rather an act of selfassertion. In his book Discipline and Punish: The Birth of the Prison, Michel Foucault contends that torture has a "juridico-political function. It is a ceremonial by which a momentarily injured sovereignty is reconstituted. It restores that sovereignty by manifesting it at its most spectacular" (p. 48). The public exhibition of the tortured body is transformed into a ritualistic performance that tends to validate the power of the state:

The confession had priority over any other kind of evidence [...]. [The production of] truth [is achieved] by a mechanism consisting of two elements- that of the investigation carried out in secret by the judicial authority and that of the act ritually performed by the accused. The body of the accused, the speaking and, if necessary, suffering body, assured the interlocking of these two mechanisms. (pp. $38-40)$

The body of the accused is molded into an undeniable palpable evidence of the justice of the state to maintain the idea of unassailable truth: "His body, displayed, exhibited in procession, tortured, served as the public support of a procedure that has hitherto remained in the shade; in him, on him, the sentence had to be legible for all" (p. 43). In Coetzee's novel, the public scene of scourging reverberates the same pattern of 'public execution' as explained by Foucault. Before this scene, all the acts of torture that accompanied the interrogation have been committed behind closed doors in the granary, away from the eyes of the settlement dwellers. After the Magistrate's imprisonment, the Third Bureau officers decide to make it public as a way to engage all the inhabitants in taking part not only in passive watching, but also in hilarious cheering that reflects a general consensus among the Empire's people concerning the annihilation of the Other: 
The Colonel steps forward [...] rubs a handful of dust into [each prisoner's] naked back and writes a word with a stick of charcoal [...] ENEMY... ENEMY... ENEMY [...]. Then the beating begins. The soldiers use the stout green cane staves $[\ldots]$. The black charcoal and ochre dust begin to run with sweat and blood [...] till their backs are washed clean. (p. 115)

Committing acts of gratuitous brutality by engraving the word 'enemy' on the naked bodies of the barbarian captives unveils the Empire's impetuous desire to reach dominion even if it means obliterating the Other. Commenting on Joll's resort to extreme violence to prove the existence of the barbarians as a real threat to the Empire, Ashcroft (2001b) contends, "the whole enterprise is manifestly absurd, that there is no threat from the barbarians [...] before the arrival of the "Third Bureau" (p. 145). The body of the Other is transformed into a space of contestation in which the Self seeks to impose its colonial presence. This is much revealed in the repeated process of beating the barbarian prisoners' backs clean, wiping the word 'enemy' from their bodies with their own sweat and blood until they become ENEMY no more. The Empire seems to create its own enemy only to destroy it. It is this circularity that makes the Empire fall into ambivalence and contradiction and blindly head towards its ultimate downfall by the end of the narrative.

Ironically, then, the barbarians' apprehension and torture tell more the trap in which colonizer's identity is caught. As a manifestation of its authority the Empire attempts to contain the Other through confinement and torture. However, the Other in Coetzee's novel is presented as an enigmatic figure, "without aperture, without entry" (p. 45), totally inaccessible to the process of examination conducted by the Magistrate. Unable to excavate the untold story of the barbarian girl, the Magistrate desperately recognizes, "To desire her has meant to enfold her, to pierce her surface and stir the quiet of her interior [...]. But with this woman it is as if there is nointerior, only a surface across which I hunt back and forth seeking entry" (p. 46). The tortured body of the Other stands as an unintelligible entity that subverts the colonial and imperial modes of representation by exposing their internal contradictions and inconsistencies. In his essay "Speechless before Apartheid," Samuel Durrant advances that the barbarian girl is presented as an "unhomely figure of and for alterity" (p. 26), embodying the history of torture that the Magistrate fails to represent. Caused by men of the Empire, her blindness renders her gaze ironically impenetrable and hence uninterpretable.

Likewise Waiting for the Barbarians, the absence of communication between Susan Barton and Friday in Foe is equally indicative of the Other's incommensurability. Friday as a colonized figure is mute because his tongue is cut out. Despite the lack of verbal communication, Susan resorts to sketching as an alternative way of interaction with Friday. But to her disappointment, "“Friday will not learn,' I said. 'If there is a portal to his faculties, it is closed, or I cannot find it" (p. 147). Friday refuses to join in the dialogue or to enter into an interaction with her. He resists disclosing his drawings to Susan's gaze in an attempt to evade her continual delving into his untold story. Feeling both frustratedand disgruntledwith Friday's muteness, Susan recognizes that language cannot establish a real exchange between Self and Other outside the frameworks of power and subjugation: "I tell myself I talk to Friday to educate him out of darkness and silence. But is that the truth? There are times when benevolence deserts me and I use words only as the shortest way to subject him to my will" (p. 60). The failure of language as a plausible vehicle of communication manifests itself in the final scene of the novel: "But this is 
not a place of words. Each syllable, as it comes out, is caught and filled with water and diffused. This is a place where bodies are their own signs [emphasis added]. It is the home of Friday" (p. 157). If a final resolution is offered in Foe, it is that the corporeality of the body becomes the site of significance not only as a potential substitute to language but more importantly as an attempt to envisage a possible communication between Self and Other beyond the logic of binarism encapsulated in dominant discourse.

Like Susan Barton, the Magistrate is interested in decoding the mystery surrounding the barbarian girl's figure. During his first encounter with her, the Magistrate asks her a number of questions that take the form of an interrogation. As a reaction, the girl meets his querulous and almost compelling attitude "with silence" (p. 28). Later on, while the Magistrate is examining her blurred eye, he asks her: "What did they do?' She shrugs and is silent” (p. 31). However, unlike Friday's silence which remains adamant throughout the narrative, except for the "slow stream" (p. 157) of air that is forced out of his mouth at the end of the narrative, the girl's silence develops from being a strategy of resistance to the process of representation into another form of non-verbal communication that tends to tell the story from the Other's perspective through the medium of the body. What follows the first encounter between the Magistrate and the barbarian girl is the nightly ritual of oiling and massaging the girl's body.

As an alternative to speaking, the girl offers her body, which bears the marks of the torture inflicted by Colonel Joll, as an encrypted message for the Magistrate to explore and decipher. At first, the mutilated body becomes an object of fascination for the Magistrate. However, his repetitive, monotonous, and most of the time nonsensical acts of massaging turn into feelings of irritation and deprivation, "It has been growing more and more clear to me that until the marks on this girl's body are deciphered and understood I cannot let go of her" (p. 33). The Magistrate's obsessional interest in the girl's marks of torture engraved on her body gradually grows into a process of probing in an attempt to comprehend what his compatriots have done in the name of Empire.

In his second visit to the granary to check on the barbarian prisoners, the Magistrate admits his role as an interrogator, "I cannot pretend to be any better than a mother comforting a child between his father's spells of wrath. It has not escaped me that an interrogator can wear two masks, speak with two voices, one harsh, one seductive" (p. 8). The Magistrate's probing for the truth is more or less analogous to Joll's. Responding to the Magistrate's curious enquiry about interrogation, Joll states:

There is a certain tone enters the voice of a man telling the truth $[\ldots]$ a special situation in which I have to probe for the truth [...]. First I get lies [...] then pressure, then more lies, then more pressure, then the break, then more pressure, then the truth. That is how you get the truth. Pain is truth; all else is subject to doubt. (p. 5)

Despite their difference at the level of methodology, both representatives of Empire overvalue the significance of truth as a fixed and conclusive meaning that can be attained either through inflicting physical pain, which is exerted by Joll, or through digging and deciphering, which are adopted by the Magistrate. 
Recognizing his role as an accomplice in the process of interrogation, the Magistrate decides to disentangle himself from the crimes committed by Col. Joll and his soldiers, "I must assert my distance from Colonel Joll! I will not suffer for his crimes!" (p. 48). In an act of challenge, or probably expiation, he crosses the borders to the barbarians' territories to return the girl to her clan. This journey marks the beginning of his dissent from the Empire's prevalent modes of representation that tends to dehumanize the Other. During the journey, the relationship between the Magistrate and the girl develops from being one between an interpreter and an enigmatic object of study, an oppressor and an oppressed, to a humane relationship between a man and a woman. They have sexual intercourse in which the Magistrate is able to penetrate the girl, both literally and metaphorically. The barbarian girl seems to offer her sexuality as a way to recuperate her voice both as woman and as an Other.

The corporeal intimacy with the girl enables the Magistrate to explore her interior. She eventually relinquishes her systematic silence, which is deployed as a strategy of resistance to the Magistrate's compulsion to tell the truth as well as the Empire's hegemonic process of othering that tends to overwrite her alterity. The barbarian girl is different now; she conspicuously fluent in talking. Stupefied, the Magistrate describes her as follows:

She is at no loss for words. I am surprised by her fluency, her quickness, her selfpossession. I even catch myself in a flush of pride: she is not just the old man's slut, she a witty, attractive young woman [emphasis added]! Perhaps if from the beginning I had known how to use this slap-happy joking lingo with her we might have warmed more to each other. But like a fool, instead of giving her a good time I oppressed her with gloom. (p. 68)

The Magistrate regrets having been blindly obsessed with exploring the girl's marks of torture rather than the girl herself. Apart from those marks, the girl was never fully seen as a whole human being; instead, she is frequently viewed as shapeless and deformed. Before his journey across the border, the Magistrate used to wonder about her mystery, "Is she truly so featureless? [...]. I see a figure in a cap and heavy shapeless coat [...]. My mouth forms the ugly word [...]. She is ugly, ugly [...]. [She] is a space, a blankness" (pp. 50-51). As a representative of the Empire, the Magistrate has treated the girl as a dehumanized Other. He has eclipsed her humanity, her individuality, and her otherness. What he sees is only the ugly signs of torture engraved on her body by the Empire. After the border-crossing experience, the Magistrate no longer sees the barbarian girl as a maimed body only. She is now a whole human counterpart, a woman with whom he falls in love.

\section{Abnegating Power to the Ailing Body}

Entangled within an interval of violence in the mid-nineteen-eighties Cape Town, Mrs. Curren, the narrator of Age of Iron, is depicted suspended on the cusp between a diseased body and a tormented soul, living with the uncertainty of rebirth and redemption. Dominic Head (2009) regards this moment as "the hovering time of interregnum" (p. 71). The analogy drawn between Mrs. Curren's personal state of interregnum is also analogous to the social and political interregnum of South Africa during the state of emergency declared by the apartheid government in the mid-eighties of the last century. Her body is metaphorically transformed into an arena for competing agendas between, on the one hand, a growing cancer like apartheid that devours the 
body of the country, and, on the other, a spiritual awakening that would bring her salvation. In spite of her professed humanist sympathies towards the Other, the rambling inter-racial violence goes beyond her control and thus weakens her physical state. It is her liminal yet relentlessly present corporeality which articulates her moral dilemma and exposes the spuriousness of her “doll”-like (p. 101) identity.

Along her encounter with the Other, Mrs. Curren comes to the realization that her world is severely debilitated as her words are ending up in a deadlock and losing their authority. Speaking of Bheki's friend, John, she discloses, "Around this boy I now felt the same wall of resistance. Though his eyes were open he did not see; what I said he did not hear" (p. 79). In a futile attempt to communicate with John, she admits, "Talk, talk! Talk had weighed down the generation of his grandparents and the generation of his parents. Lies, promises, blandishments, threats: they had walked stooped under the weight of all the talk. Not he. He threw off talk [emphasis added]. Death to talk!" (p. 144). Commenting on the black boy's reaction to Mrs. Curren educative and instructive attitude, Jane Poyner (2009) regards it as an act of "indignation at what he perceives as an empty rhetoric that resonates with South African liberalism" (p. 121). The autochthonous discourse maintained and propagated by apartheid regime fails to inscribe its authority through a self-fulfilling narrative as the young black generation, which Mrs. Curren recurrently refers to as 'iron generation,' refuses to join in the dialogue with its representatives.

In The Location of Culture, Homi Bhabha contends that cultural signs emanating from marginalized spaces can disrupt the fixity of national identity and its historical narrative:

The language of national collectivity and cohesiveness is now at stake. Neither can cultural homogeneity, or the nation's horizontal space be authoritatively represented within the familiar territory of the public sphere: social causality cannot be adequately understood as a deterministic or overdetermined effect of a 'statist' centre [...]. [The] pluralism of the national sign, where difference returns as the same, is contested bythe signifier's 'loss of identity' that inscribes the narrative of the people in the ambivalent, double 'writing' of the performative and the pedagogical. (p. 154)

In Age of Iron, the emerging voices of alterity (those of Vercueil, Thabane, Florence and her children) do not just subvert the subject position of the Self as an enunciator of the narrative.It equally interrupts the teleological course of the imperialist narrative of apartheid which primarily depends on the stability and continuity. As a result, discourse loses its authority by virtue of recurrent interruptions of communication between Mrs. Curren, who fails to express her experience of trauma after witnessing the atrocities committed by the apartheid regime, and Florence and her children, who refuse to listen and thus to participate in the formation of the narrative.

During Mrs. Curren's visit to Bheki's friend at the hospital, she first shows her repugnance from him. For her, he "has no charm"; he is "stupid", "obstructive," "intractable" and "simplified person" (p. 71). She even expresses her regrets of having nursed him in his injury. Nonetheless, despite the negative attitude she bears towards him, and probably all his comrades, Mrs. Curren's prejudice is wiped out by a spontaneous and unexpected "fingertip" (p. 
72) touch from the boy's hand. Such an inadvertent finger touch ignites, as it were, a sparkle of human interaction, revealing the interior of the Other, hitherto inaccessible to her probing. The corporeality of the body becomes the site of significance not simply as a potential substitute to language.It could be alsoread as an attempt to envisage a possible communication between Self and Other beyond the logic of binarism pervading the official discourse propagated by the state condoned mass media, which tend to promote the image of South Africa as a "land of smiling neighbours" (p. 49). Describing the spontaneous physical contact with John, she confesses:

And on an impulse [...] I touched the boy's free hand. It was not a clasp, not a long touch; it was the merest brush, the merest lingering of my fingertips on the back of his hand. But I felt him stiffen, felt an angry electric recoil [...]. My words fell off him like dead leaves the moment they were uttered. The words of a woman, therefore negligible; of an old woman, therefore doubly negligible; but above all of a white. (p. 72)

The insistence on corporal communication reveals Mrs. Curren's recognition that the language of apartheid is invalid to translate the experience of the Other. For her, body communication is capable of replacing all the words that can express such closeness and communion between subjectivities. All she needs is only a random fingertip touch to make her realize the deep chasm that separates her from the Other. She comes to the understanding that the wall that stands between her and the black youth is not so much related to gender or age; rather, it is categorically linked to her Afrikaner belonging.

In order to overcome this gap between the Self and Other, Mrs. Curren starts questioning her own identity which, according to her, is substantiallypredicated on 'whiteness.'

I, a white. When I think of the whites, what do I see? I see a herd of sheep [...] I hear a drumming of hooves, a confusion of sound which resolves itself [...] into the same bleating call in a thousand different inflections: "I!" "I!" "I!" And, cruising among them, bumping them aside with their bristling flanks, lumbering, saw-toothed, red-eyed, the savage, unreconstructed old boars grunting 'Death!' 'Death!' (pp. 72-73)

Out of a thoughtless but significantfinger touch, Mrs. Curren becomes able to see the large picture. She recognizes that the instinctive and irrational mindset is pervading both parties. She uses animal stereotypes, so long attributed to blacks, to describe her own community. For her, the white oligarchy, which is typically constructed as civilized, rational, progressivist, and democratic, is nothing but a group of sheep-like people behaving according to the herd mentality and easily manipulated by 'savage' and 'boar'-like politicians who wage death and eradication against the Other.

In order to disentangle herself from the prevailing white nationalism, Mrs. Curren claims her dissent from mainstream exclusionist discourse that makes no room for alterity to exist in its own terms. She determinedly renounces the position of the Self, the oppressor, and appropriate the position of the Other, the oppressed, to "flinch from the white touch" (p. 73). Mrs. Curren no longer wishes to remain affiliated to the white apartheid regime that makes the oppression and even the obliteration of blacks the main reason and purpose of its existence. She thinks that 
crossing the constructed boundaries between identities would offer her the chance to surmount those barriers.

After witnessing the true suffering of blacks in Guguletu, a squatter camp for blacks, Mrs. Curren loses faith in the authority of her voice. She confides to her daughter: "I may seem to understand what I say, but believe me, I do not [...]. I am feeling my way along a passage that grows darker all the time" (p. 131). She might still try to feel her way toward her daughter, however, when it comes to speaking to and of the Other, she no longer claims a subject position at all. She tells Vercueil:

"Who am I to have a voice at all? How can I urge them to turn their back on that call? What am I entitled to do but to sit in a corner with my mouth shut? I have no voice, I lost it long ago; perhaps I have never had one. I have no voice, and that is that. The rest should be silence" (p. 49).

Perhaps because the power of language is stripped off of her, her scarred body is able to speak, so to say, for itself. Her body becomes the source and vehicle of enunciation. She confesses:

What did I want? What did the old lady want? What she wanted was to bare something to them, whatever there was that might be bared at this time, in this place. What she wanted, before they got rid of her, was to bring out a scar, a hurt, to force it upon them, to make them see it with their own eyes: a scar, any scar, the scar of all this suffering, but in the end my scar, since our own scars are the only scars we can carry with us. (pp. 97-98)

As a way to resist the prevailing discourse of apartheid, Mrs. Curren gradually relinquishes the command of language and resorts to corporeality to communicate her agony. She does this by offering her ailing body and as an alternative site of significance to articulate her personal narrative. The 'I' used at the beginning of the speech shifts to the third person, 'she,' as an indication that Mrs. Curren, the enunciator of discourse in the novel, is now eclipsed from it, yielding by that her subject-position to her body. The authority of her body seems to be so straightforward, so impulsive, specifically because her life is terminating, that it demands to be heard. Rather than expressing her thoughts and feelings, she is silenced by the grim images of misery and violence she comes across during her journey to the black ghetto. Instead, she allows the scars, the signs of her ailing body, to signify what language fails to communicate.

In Age of Iron, the language of apartheid is disempowered, and the only thing left is the ailing body, which despite its powerlessness remains hermetic to discursive representation. At the end of the narrative, Vercueil is depicted holding her with "mighty force that the breath went out of [her] in a rush.From that embrace there was no warmth to be had" (p. 181). Mrs. Curren no longer has the breath with which to utter words. Her voice, the medium with which she strives to articulate her narrative, dissolves into the warmth of two bodies pressed to each other.

\section{Conclusion}

Corporeality occupies vital positions in the novels of Coetzee. The physical presence of each of the characters studied above defies any imperative or prescriptive reading. In Dusklands, the corporeal presence unsettles the Cartesian inherent binarism between a thinking essence or 
consciousness and a mechanical body that hampers and limits the cognitive faculties of the mind. According to such division, the body part is ontologically excluded from subjectivity, the seat of rationality, and is treated as a marginalized entity operating on the fringe of identity. In Waiting for the Barbarians, the body is relocated into a space of resistance to the hegemonic discourse of the Empire, which seeks to inscribe its self-realization and dominion. Despite the acts of torture and mutilation meted out to the so-called barbarians, their maimed bodies remain incommensurable to the colonial process of representation. In Age of Iron, the sick body of Mrs. Curren becomes an active agent in triggering the process of her moral awakening. It manages not only to overcome the state of inertia, the state of being a powerless and ailing entity occupying an abject position in the narrative, but also to enter an enabling space of signification.

Coetzee uses textual representations of corporeality as a subversive modalitythat dislocates processes of normalization and containment attempted by hegemonic discourses, particularly that of apartheid.It could be argued that Coetzee orchestrates corporeality as a space of resistance to the authoritative mechanisms of domination and subjectification. This authority of the body stems from its capacity to evolve from being a simply somatic substance into a more productive space of enunciation and becoming.

\section{About the Author:}

Kamel Abdaoui is currently a member of teaching staff at the Department of English, Faculty of Arts and Humanities, University of Sousse, Tunisia. Most of his academic interests and research activities (MA, PhD, and publications) revolve around literary theory, postcolonial theory and criticism, and the problematic Self/Other (hybrid) encounters in J. M. Coetzee's fiction.

\section{References}

Ashcroft, Bill. (2001a). Language. Post-Colonial Transformation. London, UK: Routledge. (pp. 56-81).

Ashcroft, Bill. (2001b). On Post-colonial Futures: Transformations of Colonial Culture. London, UK:Continuum.

Bhabha, Homi. K. (1994). The Location of Culture. London, UK: Routledge.

Coetzee, J. M. Dusklands. (1982). London, UK: Penguin Books. (Original work published 1974).

Coetzee, J. M.(2000). Waiting for the Barbarians. London, UK: Vintage. (Original work published 1980).

Coetzee, J. M. (1987). Foe. London, UK: Penguin Books. (Original work published 1986).

Coetzee, J. M.(1992). Age of Iron. New York, USA: Vintage. (Original work published 1990).

Coetzee, J. M. (1992). Doubling the Point: Essays and Interviews. David Attwell (Ed.). Cambridge, UK: Harvard UP.

Coetzee, J. M.(1996). Giving Offense: Essays on Censorship. Chicago, USA: University of Chicago Press.

Coetzee, J. M. (1999). The Lives of Animals. Amy Gutmann (Ed.). Princeton NJ, USA: Princeton University Press.

Durrant, Samuel. (2004). Speechless before apartheid. Postcolonial Narrative and the Work of Mourning. Albany, USA: State University of New York. (pp. 23-52).

Foucault, Michel. (1977). Discipline and Punish: The Birth of the Prison. Alan Sheridan (Trans.). New York, USA: Vintage Books. 
AWEJ for Translation \& Literary Studies volume, 1 Number 2, May2017

The Unruly, the Mut(ilat)ed, the Ailing: Corporeality as a Space

Abdaoui

Head, Dominic. (2009). The Cambridge Introduction to J.M. Coetzee. Cambridge, UK: Cambridge University Press.

Poyner, Jane. (2009).J. M. Coetzee and the Paradox of Postcolonial Authorship. Surrey, UK: Ashgate Publishing Limited. 